Research, part of a Special Feature on A Framework for Analyzing, Comparing, and Diagnosing Social-Ecological Systems

\title{
Adapting to Socioeconomic Developments by Changing Rules in the Governance of Common Property Pastures in the Swiss Alps
}

\author{
Ivo Baur $^{l}$ and Claudia R. Binder ${ }^{1}$
}

\begin{abstract}
The common property meadows in the Swiss Alps have been managed by local self-organized governance systems since the Middle Ages, thus preventing their overuse. During the past century, socioeconomic developments, such as industrialization and rapid nonagricultural economic growth, have shifted employment opportunities from the agricultural sector towards the service sector. In the agricultural sector, this has led to less intensive use and maintenance of the meadows in the Alps and consequently to a reduction in biodiversity. We use the example of Grindelwald in the Swiss Alps to analyze how the governance system has adapted to these socioeconomic developments. We based our analysis on the Program in Institutional Analysis of Social-Ecological Systems (PIASES). We coded five statutes ranging in date from 1867 to 2003, and conducted interviews to investigate changes in the governance system. In so doing, we focused on changes in the operational rules that structure the focal interactions between the social system and the ecological system, namely harvesting level and investment activities. Our results show that the governance system has adapted to the socioeconomic changes (1) by creating an additional organizational subunit that allows appropriators to alter operational rules relatively autonomously, and (2) through changing several operational rules. We conclude by outlining the properties of the governance system that have allowed for constant harvesting levels and investment activities over time.
\end{abstract}

Key Words: common property pastures; rules; SES; social-ecological systems

\section{INTRODUCTION}

Since the Middle Ages, summer pastures in the Swiss Alps have predominately been held as common property. At present, $80 \%$ of the summer pastures located at higher altitudes are managed as common property. Common property resources are natural or human-made resources that are jointly used and managed. In most cases, exclusion is difficult, and joint use of these resources involves subtractability (Berkes et al. 1989). In the Swiss Alps, local authorities such as cooperatives, corporations, and citizens' communes have established institutional arrangements to regulate access to the summer pastures (Picht, unpublished manuscript). The members of these organizations jointly own and manage the resources and have successfully avoided the overexploitation of summer pastures for centuries by (1) excluding outsiders, and (2) restricting the harvesting levels of the eligible users (Netting 1981, Ostrom 1990, Stevenson 1991, Tiefenbach and Mordasini 2006).

During the past century, socioeconomic developments have resulted in the decreasing use and maintenance of summer pastures. In particular, industrialization and the shift towards the service-oriented economy increased labor demand in the corresponding sectors. Thus, labor moved from the agricultural sector to the industrial and service sectors (Bergier 1984). When looking at agriculture, one can observe that in the beginning of the 19th century, alpine agriculture reached its peak in terms of land used for agriculture (Stöcklin et al. 2007). In the early 20th century, economic activities in the alpine regions were still mostly agricultural and subsistence- based, and highly dependent on livestock husbandry. The physical infrastructure, such as huts and barns, together with the summer pasture, which we refer to as "alp", were crucial assets of the community. Industrialization and the subsequent rapid expansion of the service sector created new job opportunities in the centers and brought tourism into the valleys. As a result, subsistence farming lost its importance, and the number of farmers on the alps decreased (Volken et al. 2002). The remaining farmers increased their farm size through tenure agreements, and intensified production in the productive areas, while labor-intensive pastures became less intensively used and maintained (Stöcklin et al. 2007).

The changes in land use practices that resulted were twofold: on the one hand, there was regrowth of shrubs and forests in marginal areas. On the other hand, the intensification of productive pastures (in the valley and the alps) reduced their ecological value (Stöcklin et al. 2007, Baur et al. unpublished manuscript), as extensively used pastures provide much higher species diversity than intensely used pastures or forests (Freléchoux et al. 2007, Stöcklin et al. 2007). In the 1980s, the Swiss federal government started subsidizing the summering of livestock in the alps, which reduced, but did not overcome, the trend of land abandonment in the higher regions (Baur et al. 2007, Mack et al. 2008). It is apparent that the provision of public goods such as biodiversity and the beauty of maintained landscape and infrastructure are strongly interlinked with continuous use and maintenance of the alps (Lehmann and Messerli 2007). 
Contemporary research on common property resources has predominantly investigated the social and ecological variables that allow for self-organization to avoid overexploitation of the resources (Ostrom 1990, Balland and Platteau 1996, Agrawal 2001, Dietz et al. 2003). Results of these analyses show why some groups build institutions that support them in managing resources sustainably while others do not. Furthermore, institutions and the incentives they shape are considered to be the key for economic welfare (North 1990, Acemoglu and Robinson 2012). Because the importance of institutions for the well-being of humankind is widely acknowledged, methods to analyze institutional structures have been developed in economics and social sciences (Hollingsworth 2000, Gronow 2008). These methods are designed to relate institutional structures to outcomes at one single point in time (Hodgson 1998, Ostrom 2008, Ostrom and Basurto 2011). However, the world is constantly changing and so are social-ecological systems (SESs) (Gunderson and Holling 2002, Dietz et al. 2003, Walker et al. 2004, Olsson et al. 2006, Folke et al. 2007). Accordingly, institutions need to adapt to changes occurring within and around the SES to ensure sustainable outcomes. Therefore, it is of key importance to understand the properties of governance systems and the institutions that allow them to "better cope with, manage or adjust to some changing condition, stress, hazards, risk or opportunity" (Smit and Wandel 2006:282).

We aim to contribute to the analysis of institutional change in governance systems of common property resources. We use the case of Grindelwald in the Swiss Alps to provide an indepth understanding of how the local authorities have adapted their governance system as a reaction to the socioeconomic developments in the region. We address the following questions:

1. Which variables of the social-ecological system were affected by socioeconomic developments?

2. How is the local governance system structured?

3. What changes in the local governance system have occurred over time?

4. How did the governance system adapt to socioeconomic developments?

First, we introduce the study area. Second, we describe the methods applied. Third, we present the results of the analysis as to which variables of the SES framework were affected by socioeconomic developments, including changes in the governance system. In this, we focus on changes in the operational rules that directly affect harvesting levels (number of livestock summered on the alps) and investment activities (maintenance of pastures, huts, and fences). We summarize by discussing the properties of the governance system that allow it to respond adaptively to socioeconomic developments.

\section{The study region}

Grindelwald is a Swiss municipality located in the Bernese Alps. The municipality is bounded by the mountains Eiger, Mönch, and Jungfrau, and it covers $171 \mathrm{~km}^{2}$. About $13 \%$ of the area is settlement area or agricultural area held as private property, $25 \%$ is commonly owned meadows (pastures), and $62 \%$ is unused land. The border between common property pastures (alp) and private property in the valley is shown in Fig. 1. Unique to the case of Grindelwald is the fact that seven spatially defined corporations ("Bergschaft") are embedded in a cooperative ("Taleinung"). The cooperative assigns the territory to the seven corporations. The small alp "Pfingstegg" is the only alp that is privately owned. The alp Holzmatten is a special case because it is common property but is not connected to the private property in the valley (Nägeli-Örtle 1986, Tiefenbach and Mordasini 2006).

Fig. 1. The seven corporations of Grindelwald. Adapted from Tiefenbach and Mordasini (2006). HM = Holzmatten corporation, with common property separated from the private property in the valley. The red dotted line marks the border between common property pastures (alp) and private property in the valley.

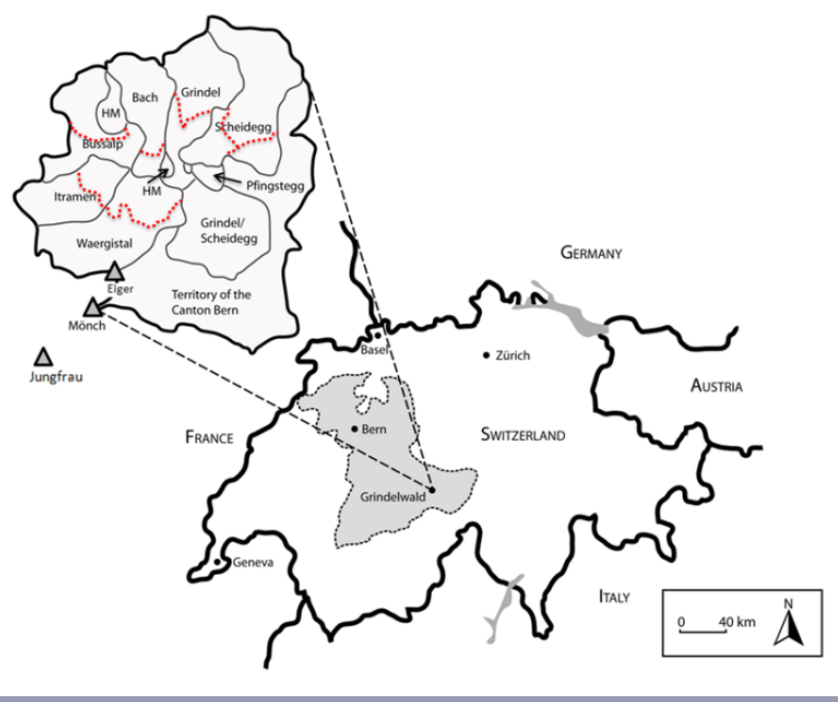

\section{METHODS}

\section{Theoretical framework}

The common property pastures in Grindelwald were analyzed as a social-ecological system (SES). According to the SES framework (Ostrom 2007, 2009), SESs are composed of four nested subsystems embedded in a broader social, economic, and political setting. As displayed in Table 1, the system's social compartment consists of the Governance System (GS) and the Actors (A). The ecological compartment entails the Resource System (RS) and the Resource Units (RU). These 
Table 1. Variables of the social-ecological system in Grindelwald affected by societal transitions. Based on Ostrom (2007, 2009), and M. McGinnis and E. Ostrom (unpublished manuscript).

Social, Economic, and Political Settings (S)

$\uparrow$ S1 - Economic development; S2 - Demographic trends; S3 - Political stability; $\uparrow S 4$ - Government resource policies; $\uparrow$ S5- Market incentives; S6 - Media organization

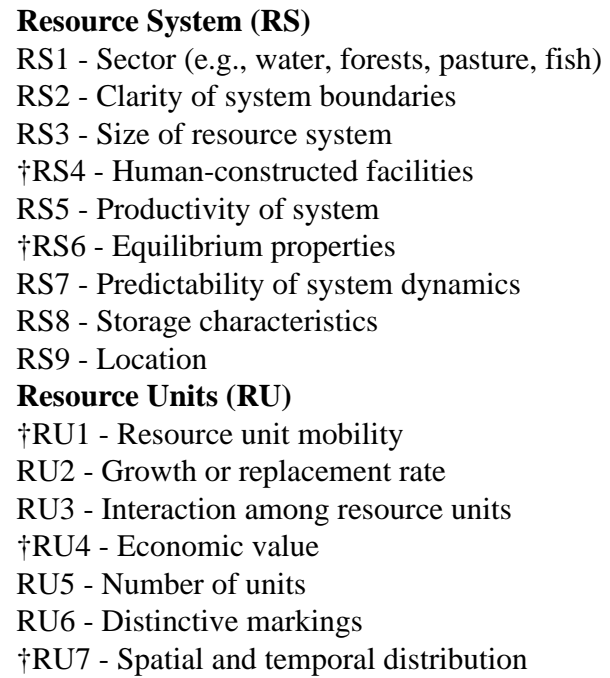

\author{
Governance System (GS) \\ GS1 - Government organizations \\ GS2 - Nongovernmental organizations \\ GS3 - Network structure \\ ‡GS4 - Property rights systems \\ \$SS5 - Operational rules \\ \$GS6 - Collective-choice rules \\ \$GS7 - Constitutional rules \\ ‡GS8 - Monitoring and sanctioning rules
}

\section{Actors (A)}

$\dagger$ A1 - Number of actors

$\uparrow \mathrm{A} 2$ - Socioeconomic attributes of actor

A3 - History of use

$†$ A4 - Location

A5 - Leadership/entrepreneurship

A6 - Norms (trust-reciprocity)

A7 - Knowledge of social-ecological system/mental models

$\dagger$ A8 - Importance of resource (dependence)

$†$ A9 - Technology used

Action Situations (Interactions [I] $\rightarrow$ Outcomes [O])

O1 - Social performance measures (e.g., efficiency, equity, accountability, sustainability)

O2 - Ecological performance measures (e.g., overharvested, resilience, biodiversity)

O3 - Externalities to other social-ecological systems

\section{Related Ecosystems (ECO)}

ECO1 - Climate patterns; ECO2 - Pollution patterns; ECO3 - Flows into and out of focal social-ecological system

$†$ Variables directly affected through socioeconomic developments

¥Governance responses by changing variables

§Focal action situations

subsystems interact (I) at various spatial and temporal scales to produce outcomes $(\mathrm{O})$.

Each subsystem can be divided into its further properties. The GS entails organizations, property rights, and a set of rules that structure interactions among actors and their use of the resource system. The property rights system (GS4) consists of a bundle of rights that regulate access and the degree of command of individual actors or organizations over a resource (Schlager and Ostrom 1992). The rules operate at three hierarchical levels: the operational level (GS5), the collectivechoice level (GS6), and the constitutional level (GS7). Hereby, the highest level (constitutional) changes at a slower pace and determines the lower ones (Ostrom 2005). For example, the constitutional level refers to the legal form of a users association as this determines who is a member and is allowed to participate in collective-choice processes. On the collectivechoice level, actors are then to agree on the operational rules according to prescribed procedures. The operational rules structure everyday interactions of users with the resources 
systems, such as harvesting or investment activities. An example of an operational rule might be a timely restriction of harvesting activities for the preservation of the resource. The resource system, which is the alp, includes the meadow and physical infrastructure, such as huts, barns, and fences. The resource system generates the resource units, which is the grass used as fodder.

The Program in Institutional Analysis of Social-Ecological Systems (PIASES) complements the SES framework by combining it with the Institutional Analysis and Development (IAD) framework (McGinnis 2011, Ostrom 2005). It thereby highlights the importance of seven operational rules that structure focal action situations (McGinnis and Ostrom 2010). In this study, we analyzed the changes in the operational rules for two focal interactions, namely harvesting levels (I1), which we operationalized as the indexed number of livestock grazing on the alps (appropriation), and investment activities (I5), which we operationalized as maintenance of the alps by communal work and the installation of fences (provision). These focal interactions determine the intensity of use and maintenance of the alps, and thus directly affect the ecological state of the resource system.

\section{Data collection and analysis}

In a first step, we conducted a workshop with farmers from the seven corporations to analyze the impact of socioeconomic developments on the SES (Table 1). In a second step, to investigate the functioning of the SES, 12 farmers, including the monitor of each corporation, were interviewed using a semistructured questionnaire (Schensul et al. 1999:149-164). Monitors keep track of appropriation and provision levels within a corporation, and lead the users association. That is, they have the best knowledge of the ongoing social and ecological processes in their corporations. In a third step, we conducted structured interviews with three monitors and the president of the cooperative to identify changes in the rules and property rights system (GS4-GS8) devised by the cooperative and corporations for the governance of the alps. Furthermore, the statutes of the cooperative named Taleinung from the years 1867, 1923, and 2002, and the statutes of the corporation "Scheidegg" from 1913 and 2003 were coded for changes in rules following the grammar for analyzing institutional statements (ADICO) (Crawford and Ostrom 1995, Basurto et al. 2009, Schlüter and Theesfeld 2010). The corporation Scheidegg was chosen as an example because of its excellent data availability. The operational rules structuring harvesting activities and infrastructural investment were organized according to the IAD framework (McGinnis and Ostrom 2010). To allow for the fact that rules might exist in form but not in practice and vice versa (Ostrom 2005), the findings were validated through three interviews with elderly farmers.

\section{RESULTS}

\section{Socioeconomic developments}

In the last century, several socioeconomic developments changed the external setting of the local SES. First, economic development (S1) created off-farm income opportunities and increased tourism considerably. This development transformed the local economy from an agriculture-based to a tourism driven economy (Fig. 2), which resulted in competition for land between touristic use (e.g., skiing, biking) and agricultural use in both the productive agricultural areas and the alps. It should be noted that the tourism sector is the main reason why Grindelwald does not suffer from emigration like other regions in the Swiss Alps, and instead has seen modest population growth (Fig. 2). Second, state control of agricultural production has steadily increased. Both production standards (S4) and market incentives (S5) have been increasingly regulated by the state through agricultural policies. Furthermore, state policies have accelerated structural change in the agricultural sector towards fewer but larger farms, and have increased farmers' dependence on direct payments. Thus, without state support, agriculture in Grindelwald is not feasible.

Due to the structural transformation of the local economy, the number of farmers owning livestock (A1) decreased from 432 to 126 within a century. During the same period, tourism increased with 863 index points, resulting in 111,728 guestnights in 2010 (Fig. 2). The remaining farmers in Grindelwald have taken advantage of the income opportunities offered by the growing tourism sector, and work on the ski lifts during the winter (A2). The decreasing number of farmers and the inheritance regulations which foresee that land is equally divided among successors, has led to dispersed farm structures in the valley (A4). Farmers who increase their farm size do so mainly through tenancy agreements, and at the cost of dissipating their land holdings. Furthermore, subsidies, offfarm income, and the use of additive fodder (A9) have reduced farmers' dependence on pastures for their livestock and dairy products for their livelihoods (A8). In addition, tourism strengthened local demand for alpine cheese (RU4).

As mentioned, intensification of the productive areas and extensification of marginal areas is also affecting the alps. Productive areas are most often close to the huts, while the marginal areas are characterized by longer walking distances, steepness, and higher altitude. Furthermore, cattle breeds have been increasing in size, and their mobility has declined as a result (RU1), which makes them less suitable for grazing in marginal areas (RU7) since long walks tend to decrease milk yield. This has impacted land cover: marginal meadows have been abandoned, bushes have started colonizing them, and the area is being transformed into forest (fir forest) (RS6). In the intensified areas, closer to huts, over-fertilization due to the high density of cows has taken place, and consequently, the 
Fig. 2. Number of overnight stays, farm enterprises and employees, and inhabitants in Grindelwald from 1910 to 2010 (Sources: Nägeli-Örtle 1986, Wiesmann 2001, Federal Statistical Office (FSO) several years).

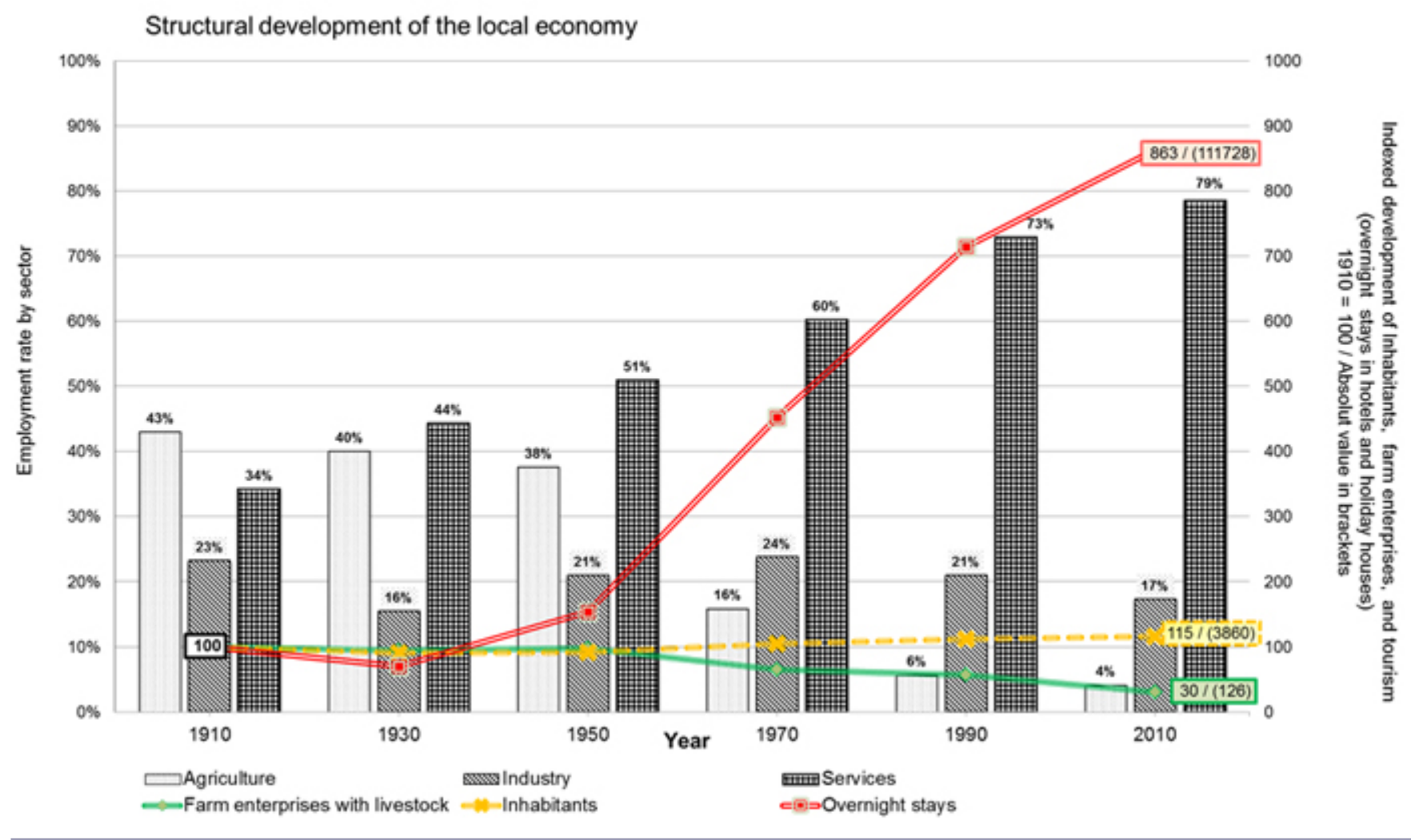

amount of persistent weeds (such as alpine sorrel or sheep sorrel [Rumex alpinus]) has increased.

Nevertheless, farmers in Grindelwald continue with their labor-intensive traditional farming system, which is based on dairy cattle farming and the seasonal cycle of transhumance, with cheese production on the alp during summer. Strategies observed in other regions, such as leisure farming, characterized by a shift from dairy cows to suckler cows or sheep husbandry, have not yet taken place in Grindelwald.

\section{The local governance system}

The local governance system in Grindelwald consists of three nested levels with their own assemblies and constitutional design:

1. the cooperative (Taleinung), where every holder of usage rights ("Bergrecht") is a member;

2. the corporations (Bergschaft), where every holder of usage rights of a specific corporation is a member; and

3. the corporations' users association ("Besetzerschaft"), where every holder of usage rights appropriating in the specific corporation becomes a member.
Rules mandatory for all corporations are designed and altered collectively by the cooperative. This ensures vertical control among the corporations by limiting the set of rules that can be crafted autonomously on the corporations' level. Similarly, the cooperative is limited in its constitutional design, since collective-choice rules and organizational principles for cooperatives are determined by cantonal and federal legislation (meta-constitutional level). Nevertheless, at each level, the lower levels still have some autonomy in designing additional rules (Fig. 3).

The cooperative (Taleinung) is an organization that functions as a legislative body in the interest of the corporations ("Bergschaften"). In its statutes ("Taleinungsbrief"), it assigns the territory to the corporations, and sets the constitutional rules, the collective-choice rules, and to some extent, the operational rules for both the corporations and the cooperative itself. The cooperative is headed by a board, which functions as the executive body. The board implements the decisions made in the assembly. The assembly is called whenever the board or a corporation decides to do so, or 100 rights holders demand it. 
Fig. 3. The structure of the local governance system in Grindelwald.

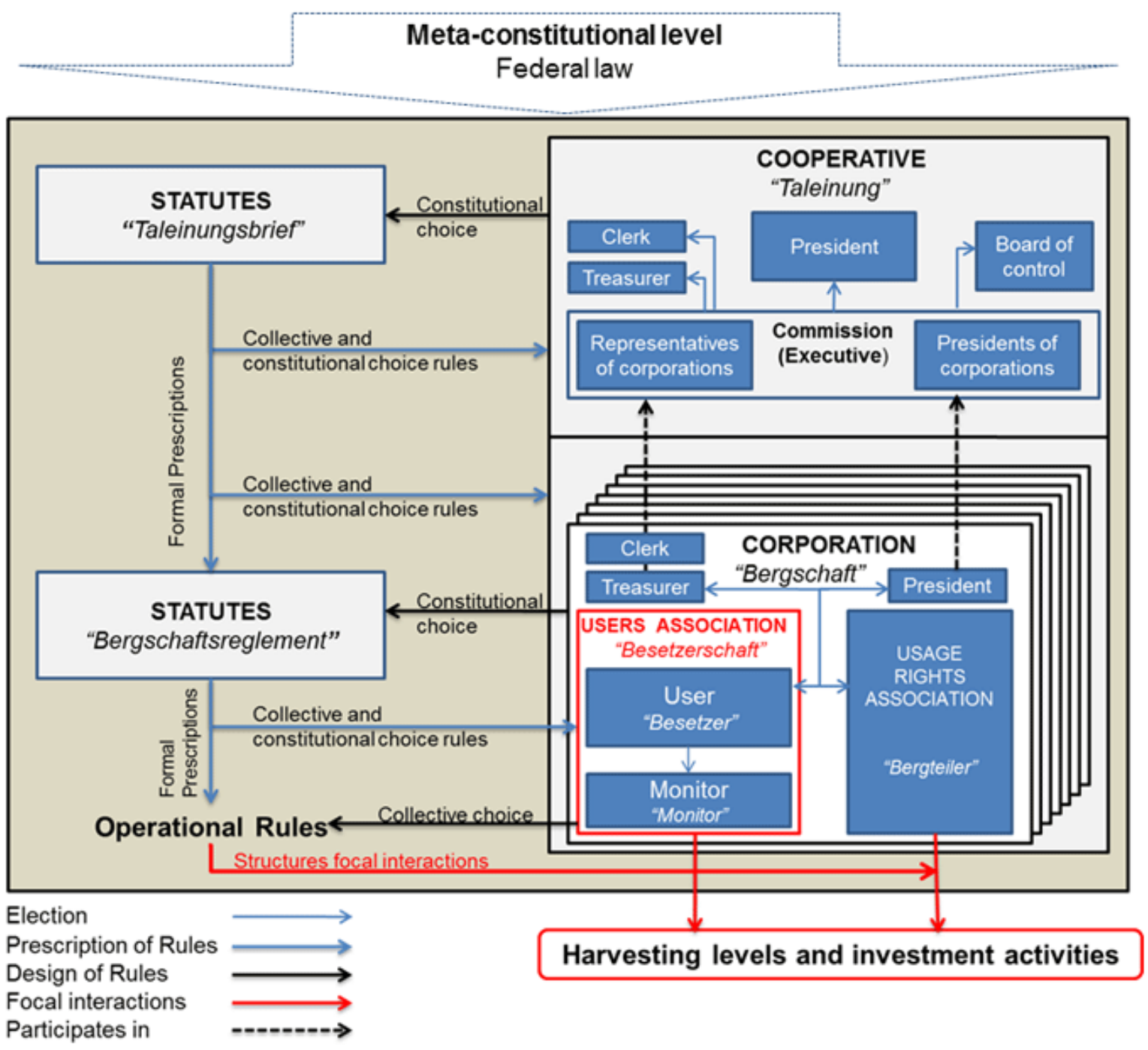

The corporation is an operational unit concerned with the management of the alp. Each corporation is obliged to have its own statutes ("Bergschaftsreglement"), which must be in agreement with the rules prescribed in statutes of the cooperative. Formal positions within corporations, such as monitors, are prescribed by the statutes of the cooperative.

Over the last century, the structure of the local governance system has changed considerably as the corporations have split into two associations, one for the users who exercise their rights of usage (Besetzerschaft), and one for the holders of rights of usage ("Bergteiler") who do not make use of their rights to harvest the pastures. The division of the corporation into Besetzerschaft and Bergteiler was first mentioned in the statutes of the cooperative in 1923. At that time, the number of rights holders not engaging in agriculture became the majority in the corporations, and their bargaining power increased to the disadvantage of farmers. Thus, the division was implemented in order to prevent conflicts over the allocation of the corporation's resources. Today, the users association and the usage rights association even have to run separate budgets as stipulated in the statutes of the cooperative from 2002. Within the users association, farmers can make autonomous decisions about the agricultural use of their respective alp. Decisions about the touristic use of the resource system are negotiated within the usage rights association.

\section{The property rights system}

The cooperative and the corporation are recognized as legal entities under civil law. The right to own natural resources such as forest, water, and pastures in common is guaranteed by cantonal law (BSG 211.1 Art. 20). The meadows and the 
forest are the property of the corporation, or their members, respectively. The cooperative prescribes that the rights of usage are attached to private parcels in the valley and that they are inalienable but leasable. Villagers owning or leasing private property are allowed to access, harvest, and manage the pastures. Formally, every holder of usage rights is allowed to send as many livestock to the alps as they have rights tied to their leasehold or privately owned parcels in the valley. The location of the private parcels determines in which corporation-alp the usage rights are to be appropriated. The sum of usage rights present in the corporation defines the maximum sustainable yield (MSY) of the corporation's alp.

Originally, this property rights system had four functions: first, the exclusion of nonvillagers; second, the assignment of harvesting levels to actors in proportion to their land holdings; third, the assignment of duties to provide infrastructural investments based on the usage rights one holds; and fourth, the definition of the MSY for each corporation. Today, usage rights still serve to exclude outsiders and assign provision duties but do not restrict the individual's harvesting activities and no longer define MSY.

During the 20th century, many private parcels that were once used as private pastures were used as land for vacation homes. Since the property rights remain attached to the plot in the valley, many rights are coupled to land that is no longer in agricultural use. Thus, while the area in the valley that is pasture land and in agricultural use has been decreasing constantly, the usage rights have not. This has resulted in an excess of usage rights, leading to a low lease fee, which in absolute terms barely changed over time. For example, in Scheidegg from 1867 to 2009, the fee for the lease of one single right for one season decreased from CHF 8.80 to CHF 8.50. That is, since the lease of rights is permitted among rights holders, and rights can be leased at very low fees, farmers' appropriation decisions are not restricted by the rights they hold. Because the rights holder is not allowed to lease unexercised rights to nonrights holders, the property rights system continues to serve to exclude outsiders. Furthermore, the opportunity to lease usage rights among local farmers allows appropriation in the corporation of their choice, regardless of the location of their privately owned parcels.

Between the two World Wars, the federal government started to estimate the MSY based on the practices found in the commonly owned pastures. Since the 1980s, the government has based its subsidies on prescribed harvesting levels. Payments related to the summering of livestock are incrementally reduced if total appropriation does not remain within $75-110 \%$ of the sustainable yield as defined by the canton (BLW 2010). These subsidy rules offer the corporation strong monetary incentives to keep appropriation within a sustainable range, including a minimum harvesting level. Since summering payments are conditioned on maximum and minimum harvesting levels, state policies determine the MSY for the alps. Because breeding has increased cow size, milk yields, and the cows' fodder needs, the total number of usage rights would no longer reflect the MSY of the alps, and the appropriation of all usage rights would result in serious damage and overharvest of the summer pastures, especially in the easily accessible areas.

\section{Rules}

Statutes entail different constitutional rules (GS7) that determine the collective-choice as well as operational rules for the corporations. The statutes of the cooperative thus stipulate that the corporations must keep the rules within the statutes of the cooperative.

Collective-choice rules (GS6) are prescribed for each level in the statutes of the superior level. At present, collective choices are made at all levels according to the majority rule $(50 \%+1)$. If no majority is obtained, presidents have the deciding vote in the cooperative and in the corporation, and act as monitor in the users association.

Operational rules (GS5) directly regulate appropriation and infrastructural investments, and are defined at various levels. The cooperative defines the boundary rules (ownership of land in the valley) and position rules (e.g., "appropriator" and "rights holder"). The corporation's statutes stipulate that every holder of property rights must invest in infrastructure by installing a defined length of fence on the alps in proportion to the rights they hold. Furthermore, it prescribes that every appropriator has to provide communal work in proportion to their personal harvesting levels. The users assembly defines and changes sensitive operational rules, mainly the payoffs that affect appropriation and investment levels. For example, the users association may set the hours of communal work required per appropriated livestock unit and the monetary fines for underprovision of communal work.

The monitoring (GS8) of the individual's compliance with appropriation and provision rules is a jointly shared task of all farmers. The monitor is to be informed about any unjustified appropriation and has to confiscate the trespassing livestock. Furthermore, they have to control the provision of infrastructural investment and penalize noncompliance through fines. For most of the violations of operational rules, such as underprovision of communal work or failure to install a fence, the catalogue of fines is defined every year by the users association. If a violator has not paid their fine by the start of the following season, they lose their property rights until the fine is paid. In the case of violation of constitutional or collective-choice rules by corporations, a forfeit can be set by the cooperative's board.

\section{Adaptation of rules}

As shown in Table 2, we found several changes in the operational rules that directly structure appropriation and provision situations. 
Table 2. Rule inventory: displays the level that enforces the operational rule at certain points in time. It shows the seven types of operational rules that directly structure the adjacent action situations appropriation (A) and the provision of infrastructural investment $(\mathrm{P})$. The rule codes are as follows: $\mathrm{R}=$ the rule must be complied with; $\mathrm{P}=$ the rule may be complied with; $\mathrm{P}^{*}=$ the rule may be complied with, but agreement from the cooperative board is required; $\mathrm{F}=$ the rule does not have to be complied with; n.r. = no rules exist at this time. MSY = maximum sustainable yield.

\begin{tabular}{|c|c|c|c|c|c|c|}
\hline \multirow[b]{2}{*}{ Types of rules } & \multicolumn{3}{|c|}{$\begin{array}{r}\text { Cooperative } \\
\text { (Taleinung) }\end{array}$} & \multicolumn{2}{|c|}{$\begin{array}{l}\text { Corporation } \\
\text { (Scheidegg) }\end{array}$} & \multirow{2}{*}{$\begin{array}{c}\text { User } \\
\text { assembly } \\
\text { (Scheidegg) } \\
\text { current }\end{array}$} \\
\hline & 1867 & 1923 & 2002 & 1912 & 2003 & \\
\hline \multicolumn{7}{|l|}{ Position rules } \\
\hline AP1: Appropriator (member of the users association) & n.r. & $\mathrm{R}$ & $\mathrm{R}$ & $\mathrm{R}$ & $\mathrm{R}$ & $\mathrm{R}$ \\
\hline $\begin{array}{l}\text { AP2: Rights holder (holds rights but does not } \\
\text { appropriate) }\end{array}$ & n.r. & $\mathrm{R}$ & $\mathrm{R}$ & $\mathrm{R}$ & $\mathrm{R}$ & $\mathrm{R}$ \\
\hline PP1: Provider of infrastructural investments & $\mathrm{R}$ & n.r. & n.r. & $\mathrm{R}$ & $\mathrm{R}$ & $\mathrm{R}$ \\
\hline \multicolumn{7}{|l|}{ Boundary rules } \\
\hline $\begin{array}{l}\text { AB1: Appropriator; must be appropriating during } \\
\text { current season }\end{array}$ & n.r. & $\mathrm{R}$ & $\mathrm{R}$ & $\mathrm{R}$ & $\mathrm{R}$ & $\mathrm{R}$ \\
\hline AB2: Rights holder; must own land in the valley & $\mathrm{R}$ & $\mathrm{R}$ & $\mathrm{R}$ & n.r. & $\mathrm{R}$ & $\mathrm{R}$ \\
\hline $\begin{array}{l}\text { BP1: Appropriator; becomes provider of communal } \\
\text { work and fencing }\end{array}$ & $\mathrm{R}$ & n. $r$. & n. $r$. & $\mathrm{R}$ & $\mathrm{R}$ & $\mathrm{R}$ \\
\hline BP2: Rights holder; becomes provider of fencing & n.r. & n. r. & $\mathrm{R}$ & n.r. & $\mathrm{R}$ & $\mathrm{R}$ \\
\hline \multicolumn{7}{|l|}{ Choice rules } \\
\hline $\mathrm{AC} 1$ : Lease of rights (to or from holder of usage rights) & $\mathrm{P}$ & $\mathrm{P}$ & $\mathrm{P}$ & $\mathrm{P}$ & $\mathrm{P}$ & $\mathrm{P}$ \\
\hline $\begin{array}{l}\text { PC1: Provision levels; pay fine instead of providing } \\
\text { communal work }\end{array}$ & n.r. & n.r. & n.r. & n.r. & $\mathrm{P}$ & $\mathrm{P}$ \\
\hline PC2: Fencing; pay fine instead of installing fence & n.r. & n.r. & n.r. & n.r. & $\mathrm{R}$ & $\mathrm{R}$ \\
\hline PC3: Delegation of provision activities to proxy & $\mathrm{F}$ & n. r. & $\mathrm{P}$ & n. $r$. & $\mathrm{P}$ & $\mathrm{P}$ \\
\hline \multicolumn{7}{|l|}{ Information rules } \\
\hline AI1: Standardized measurement for appropriation & $\mathrm{R}$ & $\mathrm{R}$ & $\mathrm{R}$ & n. r. & $\mathrm{R}$ & $\mathrm{R}$ \\
\hline $\begin{array}{l}\text { AI2: Reporting of illegal appropriation to higher } \\
\text { instance }\end{array}$ & n.r. & $\mathrm{R}$ & n.r. & n.r. & $\mathrm{R}$ & $\mathrm{R}$ \\
\hline PI1: Reporting of provision levels & $\mathrm{R}$ & $\mathrm{R}$ & n.r. & $\mathrm{R}$ & $\mathrm{R}$ & $\mathrm{R}$ \\
\hline PI2: Reporting of fencing levels & n.r. & n.r. & n.r. & n.r. & $\mathrm{R}$ & $\mathrm{R}$ \\
\hline \multicolumn{7}{|l|}{ Aggregation rules } \\
\hline AA1: Agreement on the appropriation of external cattle & $\mathrm{F}$ & $\mathrm{P}^{*}$ & $\mathrm{P}^{*}$ & $\mathrm{~F}$ & $\mathrm{P}^{*}$ & $\mathrm{R}$ \\
\hline $\begin{array}{l}\text { AA2: Agreement when to drive livestock up and down } \\
\text { from the Alps }\end{array}$ & n.r & n.r & n.r & n.r & n.r & $\mathrm{R}$ \\
\hline AA3: Collective choice rules: proportional to shares & $\mathrm{P}$ & $\mathrm{F}$ & $\mathrm{F}$ & $\mathrm{P}$ & $\mathrm{F}$ & $\mathrm{F}$ \\
\hline $\mathrm{AB} 1$ : Defining the levels of provision required & n.r. & n.r. & n.r. & n.r. & $\mathrm{R}$ & $\mathrm{R}$ \\
\hline AB2: Reimbursement of additional contribution & n.r. & n.r. & $\mathrm{P}$ & n.r. & $\mathrm{P}$ & $\mathrm{R}$ \\
\hline \multicolumn{7}{|l|}{ Payoff rules } \\
\hline AP1: Setting the interest for the lease of shares & n.r. & $\mathrm{R}$ & n.r. & $\mathrm{P} *$ & $\mathrm{R}$ & $\mathrm{R}$ \\
\hline AP2: Reimbursement for unused shares & $\mathrm{R}$ & $\mathrm{R}$ & n.r. & n.r. & n.r & $\mathrm{P}$ \\
\hline AP3: Fixed penalty for unreported appropriation & $\mathrm{R}$ & $\mathrm{R}$ & n.r. & $\mathrm{R}$ & $\mathrm{R}$ & $\mathrm{R}$ \\
\hline AP4: Price for appropriating a livestock unit & n.r. & $\mathrm{R}$ & n.r. & $\mathrm{R}$ & $\mathrm{R}$ & $\mathrm{R}$ \\
\hline PP1: Fees for under/overprovision of communal work & $\mathrm{R}$ & n.r. & n.r. & $\mathrm{R}$ & $\mathrm{R}$ & $\mathrm{R}$ \\
\hline PP2: Fees for not fencing & $\mathrm{R}$ & n.r. & n.r. & $\mathrm{R}$ & $\mathrm{R}$ & $\mathrm{R}$ \\
\hline \multicolumn{7}{|l|}{ Scope rules } \\
\hline $\begin{array}{l}\text { SA1: Respecting MSY; appropriation must remain } \\
\text { within MSY of corporation }\end{array}$ & n.r. & $\mathrm{R}$ & n.r. & $\mathrm{R}$ & n.r & $\mathrm{R}$ \\
\hline $\begin{array}{l}\text { SP1: Infrastructural investments must serve agricultural } \\
\text { purpose }\end{array}$ & n.r. & $\mathrm{R}$ & $\mathrm{R}$ & n.r. & $\mathrm{R}$ & $\mathrm{R}$ \\
\hline
\end{tabular}


Including constitutional, collective, and operational rules, seven key changes have occurred over the last century, which are worth summarizing:

1. At the constitutional level, since the beginning of the 20th century, the cooperative has prescribed that the corporations must be divided into a users association and a usage rights association.

2. At the collective-choice level, voting procedures prescribed for all levels have been refined. In the statutes of 1923, it was mentioned that voting can be conducted in proportion to the rights one holds, if 20 rights holders or the board demand it at the cooperative level, or the board or 10 rights holders do so at the corporation level. This option was eliminated in the statutes of 2002, since it is not in agreement with the voting procedures for corporations and cooperatives as defined in civil law. At present, every actor holding property rights is assigned one vote.

3. At the operational level, the differentiation between the positions "appropriator" and "rights holder" led to the diversification of rules for the provision of infrastructural activities. The statutes of 1867 prescribe that any holder of rights is obliged to keep their share of the alp in a good state. Accordingly, every rights holder was automatically urged to become a provider of public infrastructure, including fencing and communal work. Infrastructural investments were set in proportion to the usage rights that an actor held, and did not depend on their appropriation, as is the case today. Currently, a rights holder becomes a provider of fencing in proportion to the rights they hold, and the appropriator becomes a provider of communal work in proportion to their harvesting level. A novelty is that the statutes of 2002 allow appropriators to delegate their duties, which has resulted in farmers' spouses engaging in the maintenance of the alps.

4. Appropriation of "foreign" cattle has become permitted pending agreement of the cooperative. Although usage rights were always tied to private property in the valley, the cooperative's statute of 1923 contains the clause that if the livestock population in the valley is significantly reduced "due to forces of nature," the corporations are allowed to admit foreign cattle to the alps, if the cooperative board permits it. At present, questions are raised over whether (foreign) cattle that do not belong to rights holders can be appropriated. The commission has recently allowed the corporation Scheidegg to appropriate foreign cattle, even in the absence of a natural hazard that reduces livestock populations.

5. Over the past century, the rules affecting the payoffs for appropriation and the provision of infrastructural investment came to be totally under the jurisdiction of the corporations. The constitution of the cooperative from 1923 still entailed fixed rental fees for the lease of a right distinguished for the seven corporations. Nowadays, the prices for the lease of a right are defined by the users association and are very low (CHF 8.50 per right in the case of Scheidegg). Similarly, the corporations can now decide whether they will reimburse for unused shares; this was compulsory in the earlier statutes. Most of the payoff rules affecting infrastructural investment are set by the users association. The users association can decide about the hours of communal work they require per appropriated unit. The Scheidegg corporation is currently requesting 8 hours per appropriated unit. Penalties for not providing communal work, and the reimbursement of additional hours of communal work are autonomously set by the corporations. That is, farmers decide whether they contribute in coin or in kind. Furthermore, farmers are offered the opportunity to generate additional income by working more than the required hours. Currently, payments in the Scheidegg corporation for overcompensation are fixed at CHF 20 per hour, while the fee for undercompensation is CHF 25 per hour. If farmers carry out communal work with light private machinery (e.g., a chainsaw) or with heavier private machines, such as smaller carriers for the dispersal of manure, hours are counted double or even fourfold, respectively. However, these fees and payments can always be changed by the users association, and by altering them, the users association guarantees a steady level of provision of communal work within the corporation. Similarly, the cooperative allows the corporations to set the tariffs for failure to fence (one right is equivalent to $15 \mathrm{~m}$ ). Actors who hold usage rights but do not engage in agricultural activities are charged CHF 1.50 per meter that they do not fence. This has become an additional source of income for the corporation.

6. A newly added rule states that the infrastructure, particularly huts and barns on the alp, must not be used for purposes other than agricultural, and that they cannot be sold to externals. This was allowed in older versions, if the cooperative board agreed. The change in this rule ensures that the huts are not transformed into recreational infrastructure.

7. Since the introduction of summering payments in the 1980 s, MSY is ensured through agricultural policy incentives. The total number of usage rights therefore no longer defines the MSY of the alp. The summering payments are conditioned upon a minimum harvesting level in order to increase incentives to use the alps more intensively. Today, these payments are tied to a minimum $(75 \%)$ and maximum $(110 \%)$ harvesting level of the state-defined sustainable yield. In 2010, Scheidegg hosted $103 \%$ of the MSY (Table 2). 


\section{DISCUSSION}

We analyzed whether and how local governance systems governing the management of common property meadows in the alps in Grindelwald have adapted to socioeconomic changes. We applied the SES framework to identify the relevant variables within the SES that have changed due to socioeconomic developments, and we used PIASES in order to identify changes in the rules within the governance system. Our study is original in its contribution because it empirically analyzes changes in rule configurations in the governance of common property resources. Additionally, it links the observed changes in rules to changes in the social-ecological context. Therefore, our study supports the development of a general theory of institutional change and a better understanding of the conditions that enhance the capacity of governance systems to change rules successfully.

\section{Socioeconomic changes and their impact on the social- ecological system}

In the following, we link the impact of the socioeconomic developments in Grindelwald (industrialization, rapid nonagricultural economic growth, subsidy scheme in agriculture) on the variables of the SES, in particular, the changes in the governance system (Table 3). We focus on the main key reactions of the governance system to these changes.

\section{Changes in the governance system as a response to socioeconomic development}

\section{Adapting to a decreasing number of rights holders making use of their rights}

Socioeconomic developments have led to a decreasing number of appropriators and an increasing number of rights holders who are not engaging in agriculture (Fig. 3). As a response to this shift in bargaining power, at the level of the cooperative the decision was made to restructure the corporations by dividing them into a rights holders association and a users association. This division ensures that farmers decide relatively autonomously within the users association about the operational rules they apply to govern the agricultural use of the alps. In particular, the ability to alter payoffs for appropriation (e.g., setting the price for the lease of a right) and provision (e.g., setting the fees for under- and overprovision) allows them to balance harvesting and investment activities at the corporation level.

The distinction between the position of an appropriator and a rights holder, furthermore, allowed the provision rules to be adapted, which led to a more flexible labor allocation for investment activities. Initially, communal work and fencing were in proportion to the number of the usage rights one held. Currently, communal work is tied to the appropriation level of an individual, while the duty to install fencing remains proportionate to the usage rights one holds. The actual provision rules allow farmers to plan whether they will pay fines or contribute with labor and machinery work to fulfill their obligations. Additionally, they are free to provide more than the required fences or hours of communal work and to be reimbursed by the corporation or to delegate the provision duties to a proxy. Hence, changes in provision rules increased the flexibility of the single user to contribute with respect to their opportunity costs and machinery assets, which is very likely to increase overall productivity of investment activities in any SES. The fact that provision rules assign different investment activities to different positions is considered key to ensuring high levels of cooperation in the provision of investment activities.

\section{Adapting to declining numbers of cattle and national subsidy schemes}

As shown in Fig. 4 for the corporation of Scheidegg, the number of cows in the region has been decreasing. Furthermore, summering subsidies are tied to the number of cows harvesting meadows on the alps and are paid only if the harvesting level is higher than $75 \%$ and less than $110 \%$ of the MSY. To adapt to this situation, operational rules were changed to allow the possibility to agree upon the appropriation of foreign cattle. It has been observed that some corporations have started hosting livestock that are not owned by local farmers. The result of this adaptation strategy on the MSY in shown in Fig. 4, which depicts the initial MSY, which still exists in form but not in use. The introduction of summering payments had two major effects on the local governance system. First, MSY is now defined through summering payments as they are tied to state defined MSY. Second, the payments shaped stronger incentives for the summering of cattle, which is the reason why the Scheidegg corporation is currently hosting about 40 foreign cows during the summer.

\section{The role of a multileveled governance system for sustainable common property management}

Our results show that the local governance system in Grindelwald is a complex system with three levels that have changed its constitutional rules toward a more subsidiary design by creating an additional level. The cooperative (Taleinung) constitutes the highest level and includes seven corporations (Bergschaft). The creation of the additional level, which is the users association, allows farmers to govern the agricultural affairs of the corporation without involvement of tourism entrepreneurs. Furthermore, our findings suggest that these multilayered governance systems enhance the capacity to handle scale-dependent and cross-scale issues (Cash et al. 2006, Berkes 2007, Termeer et al. 2010), and provide a basis for linking local knowledge, action, and the state of the socialecological system (Lebel et al. 2006). In the case of Grindelwald, the changes in the structure of the local governance system enhanced farmers' capacity to create and alter operational rules within the users association. At this level, farmers are best informed about harvesting and investment activities and have the strongest interest in finding 
Table 3. Variables of the social-ecological system framework affected by external socioeconomic developments (industrialization, rapid nonagricultural economic growth, subsidy scheme in agriculture) for the case of Grindelwald.

\begin{tabular}{|c|c|}
\hline Variables & Changes that occurred \\
\hline \multicolumn{2}{|l|}{ Resource System (RS) } \\
\hline \multirow{3}{*}{$\begin{array}{l}\text { RS4 - Human constructed } \\
\text { facilities }\end{array}$} & •Unused alp-huts (mainly cheese storage huts) \\
\hline & •Modernized barns (e.g., heating, electricity) \\
\hline & $\begin{array}{l}\text {-Increased facilities for tourism, such as restaurants, ski lifts, or water reservoirs for artificial snow } \\
\text { production, led to reduced grazing area }\end{array}$ \\
\hline \multirow[t]{2}{*}{ RS6 - Equilibrium properties } & $\begin{array}{l}\text {-Decreasing harvest in the marginal areas on the alps has led to observable forest and bush } \\
\text { encroachment }\end{array}$ \\
\hline & -Areas covered with forest have increased at the expense of the grazing areas \\
\hline \multicolumn{2}{|l|}{ Resource Units (RU) } \\
\hline RU1 - Resource unit & -Decreasing mobility of cows due to new breeds \\
\hline mobility & •Pastures that are further away from huts/barns are not "harvested" \\
\hline \multirow[t]{2}{*}{ RU4 - Economic value } & $\begin{array}{l}\text {-Economic value of milk and milk products has significantly decreased in net value over time } \\
\text {-Farm gate prices for milk have decreased from about CHF } 1 \text { in the early 1990s to CHF } 0.45 \text { at } \\
\text { present }\end{array}$ \\
\hline & $\begin{array}{l}\text {-Tourism in Grindelwald ensures a high demand for alpine cheese, thereby increasing the relative } \\
\text { value of alpine cheese to milk sales }\end{array}$ \\
\hline $\begin{array}{l}\text { RU7 - Spatial and temporal } \\
\text { distribution }\end{array}$ & • Grazing in marginal areas has been reduced as cows became less mobile \\
\hline
\end{tabular}

Actors (A)

A1 - Number of actors
A2 - Socioeconomic
attributes
A4 - Location

A8 - Importance of resource

A9 - Technology used

Governance System (GS) GS4 - Property rights systems

GS5 - Operational rules
-Slightly increasing number of rights holders

-Increasing number of holders of rights not engaging in agriculture

-Income diversification (off-farm income share increased)

-Increasing farm sizes (farmers own more livestock and private land than the previous generation) -Farm enterprises consist increasingly of dispersed private land holdings in different corporations - Farmers therefore often hold use rights in several corporations, and the location of the farm is no longer the single factor determining the corporation in which the farmer appropriates his cattle

-Decreasing importance of meadows as a resource for cow fodder

-Increasing importance of meadows for landscape beauty and recreational activities (for tourism)

-Technologies such as modern mowing and transport machineries, or milking technologies have particularly increased productivity on the farm level. On the alps, farmers can use some of their private machinery in order to fulfill their investment requirements.

-Serves to exclude nonvillagers

- No longer required for the assignment of harvesting levels

-No longer used to assign the hours of communal work to be fulfilled

-The total number of user rights no longer defines the maximum sustainable yield

-Division between the position of the appropriator and the rights holder; provision rules tied to these two positions

-Hours of communal work conducted with light machinery (e.g., a jigsaw) are counted double -Hours of communal work conducted with heavy machinery (e.g., a small transporter) are counted fourfold

GS6 - Collective-choice rules

GS7 - Constitutional rules

GS8 - Monitoring and sanctioning rules
-Voting within the association was conducted according to the rights one holds

- Currently, all collective choices are made at all levels according to majority rule $(50 \%+1)$

- Corporations were divided into a rights holders association and a users association

-In addition, payoff rules can now be autonomously set by the users association, mainly through the setting of fees for over- and underprovision of communal work

-Sanctions were prescribed at the cooperative level

- Currently, most of the penalties for noncompliance regarding the fulfillment of infrastructural investments are set within the users association 
Fig. 4. Changes in maximum sustainable yield, constant appropriation, number of rights users, and number of rights holders in the Scheidegg corporation.

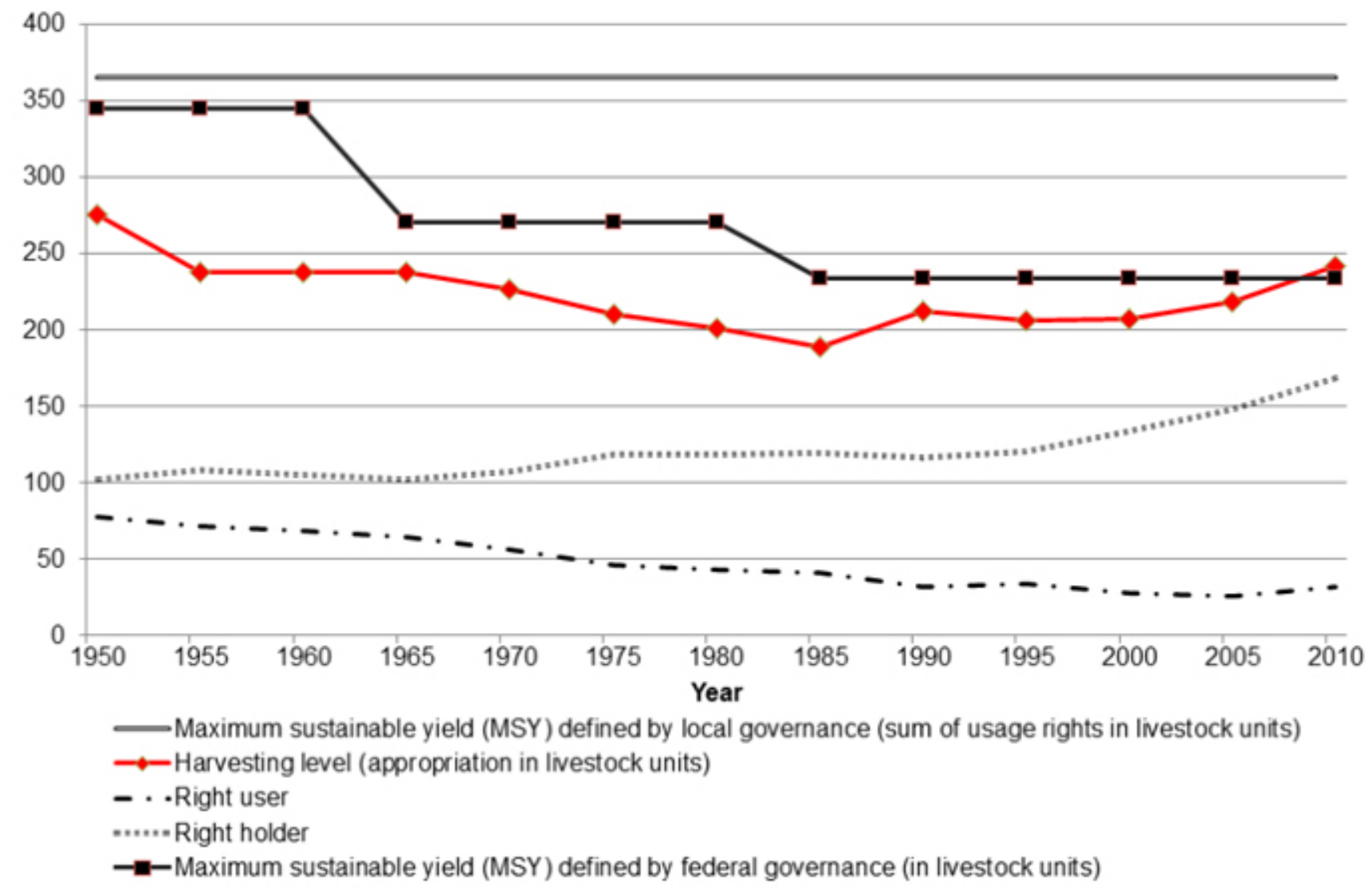

adaptive responses to fluctuations in these two focal interactions because they are most affected by the outcomes. The horizontal interplay between the corporations is ensured through the presence of the cooperative and binding statutes. Some operational decisions, such as the appropriation of foreign cattle, can be realized only under the agreement of the cooperative, which allows for checks among corporations. Interlinks with federal law and resource policies have similarly grown stronger as summering payments have become an essential monetary incentive for farmers to keep appropriation within a sustainable range.

\section{Utility of the social-ecological system framework}

The SES framework allowed for a systemic analysis of the changes that occurred in the SES, given external socioeconomic developments. As shown in Tables 1-3, the classification along the variables for the SES framework allowed for a structured analysis of the changes in the SES and supports the understanding of how the governance system adapted to changes in other variables of the SES. As the SES framework and the proposed governance variables are rooted in the IAD framework, its key strength lies in the analysis of rules, and the way they structure interactions and outcomes. Furthermore, the framework allows institutional change to be related to changes in the natural resource system because it offers a set of resource-related variables that may affect the governance process. This suggests that the framework is particularly suitable for studies that focus on the social compartment of a SES. Scholars emphasizing the ecological processes within an SES might find frameworks originating in the natural sciences to provide better concepts for their purpose (Redman et al. 2004, Walker et al. 2004, Turner and Robbins 2008). The future integration of these concepts into the present SES framework would be a major step towards a common framework that allows for analysis of equal depth for both the ecological and social compartment of SESs.

\section{Lessons learned}

It became evident that analysis of the changes in the structure and rules of the governance system is essential if we want to 
look into the dynamics and potential adaptation mechanisms within SESs. As our study has shown, the governance system in Grindelwald adapted to socioeconomic developments by changing rules. Even if the governance system was originally designed to avoid overuse of the resources, it managed to adapt to socioeconomic changes that would have led to reduced use and maintenance of the alps. Although the observed changes in the governance system and its rules are successful adaptations in this case, they might be far from optimal if applied to other contexts. Accordingly, it cannot be assumed that the rule configuration as reported herein serves as a blueprint for effective rule evolvement for the governance of common property resources. However, based on the findings, we suggest four properties of governance systems that facilitate successful adaptation of rules to socioeconomic changes:

- Constitutional flexibility: allows the governance system to adapt its structure to problems such as the decreasing bargaining power of those most interested in the productivity of the resource system

- Multiple nested assemblies: allows competencies among different assemblies to be located, which ensures that an arising issue is processed in the corresponding assembly

- Polycentric design: ensures vertical integration and control between user groups about the rules they are crafting, and at the same time ensures the flow of information about the performance of rule configurations

- Subsidiary design: allows changing the rule configuration by the people best informed about the state of the system

\section{Future research}

Future studies that address the dynamics of SESs should focus on further investigating the linkage between changes in the SES and changes in the governance system. We have shown that for the case of Grindelwald, a close relationship can be postulated. These studies need to further elaborate the patterns of rule evolvement, and to relate them to changes in the SES and outcomes. Such research will provide a better understanding of the properties of governance systems that allow for effective rule change, and thus provide the empirical base for the general theory of institutional change, applicable to the governance of common property resources. Furthermore, a simulation model might support the assessment of strategies that support or hinder the sustainable development of the SES given its external and internal dynamics and regulatory structures.

Responses to this article can be read online at: http://www.ecologyandsociety.org/issues/responses. $\mathrm{php} / 5689$

\section{Acknowledgments:}

This paper has been produced as a part of the project "Analyzing and Modeling Transitions of Common Property Pastures in the Swiss Alps," funded by the Swiss National Science Foundation. Any opinions, findings, or implications expressed herein do not necessarily reflect the view of the funding agency. The project is led by the Chair of HumanEnvironment Relations in the Department of Geography at Ludwig-Maximilians University of Munich, Germany. Research is carried out in collaboration with the Centre for Development and Environment (CDE), University of Bern; the Agri-Food and the Agri-Environmental Economics Group at the Swiss Federal Institute of Technology-ETH; and the Workshop in Political Theory and Policy Analysis at Indiana University, Bloomington. The authors would like to thank the project partners: Urs Wiesmann and Karina Liechti of the CDE, University of Bern, Switzerland; Bernard Lehmann of the Federal Office for Agriculture, Switzerland; and Elinor Ostrom of Indiana University, USA. Additionally, the authors would like to thank Michael Kirk, University of Marburg, Germany; Matthias P. Finger of the Swiss Federal Institute of Technology-EPFL, Switzerland; and Pieter Bots of TU Delft, Netherlands for comments on earlier versions of this paper, and Heather Murray for editing. Furthermore, thanks are due to the farmers of Grindelwald, Switzerland who supported and enabled our work through their collaboration.

\section{LITERATURE CITED}

Acemoglu, D., and J. Robinson. 2012. Why nations fail: the origins of power, prosperity, and poverty. Crown Business, New York, New York, USA.

Agrawal, A. 2001. Common property institutions and sustainable governance of resources. World Development 29:1649-1672. http://dx.doi.org/10.1016/S0305-750X(01) 00063-8

Balland, J., and J. Platteau. 1996. Halting degradation of natural resources, is there a role for rural communities? FAO and Clarendon Press, Oxford, UK.

Basurto, X., G. Kingsley, K. McQueen, M. Smith, and C. M. Weible. 2009. A systematic approach to institutional analysis: applying Crawford and Ostrom's grammar. Political Research Quarterly 63:523-537. http://dx.doi.org/10.1177/1065912909334430

Baur, P., P. Müller, and F. Herzog. 2007. Alpweiden im Wandel. Agrarforschung 14:254-259.

Bergier, J. F. 1984. Histoire économique de la Suisse. Payot, Lausanne, Switzerland.

Berkes, F. 2007. Community-based conservation in a globalized world. Proceedings of the National Academy of 
Sciences of the United States of America 104:15188-15193. http://dx.doi.org/10.1073/pnas.0702098104

Berkes, F., D. Feeny, B. J. McCay, and J. M. Acheson. 1989. The benefits of the commons. Nature 340:91-93. http://dx. doi.org/10.1038/340091a0

Bundestamt für Landwirtschaft (BLW) 2010. Sömmerungsbeitragsverordnung (SöBV). Sömmerungsbeitragsverordnung, SöBV; SR910.133. BLW. [online] URL: http://www.blw. admin.ch/themen/00006/00052/index.html?lang

Cash, D. W., W. N. Adger, F. Berkes, P. Garden, L. Lebel, P. Olsson, L. Pritchard, and O. Young. 2006. Scale and crossscale dynamics: governance and information in a multilevel world. Ecology and Society 11(2):8. [online] URL: http:// www.ecologyandsociety.org/vol11/iss2/art8/

Crawford, S. E. S., and E. Ostrom. 1995. A grammar of institutions. American Political Science Review 89(3):582600. http://dx.doi.org/10.2307/2082975

Dietz, T., E. Ostrom, and P. C. Stern. 2003. The struggle to govern the commons. Science 302:1907-1912. http://dx.doi. org/10.1126/science.1091015

Folke, C., L. Pritchard, F. Berkes, J. Colding, and U. Svedin. 2007. The problem of fit between ecosystems and institutions: ten years later. Ecology and Society 12(1):30. [online] URL: http://www.ecologyandsociety.org/vol12/iss1/art30/

Freléchoux, F., M. Viret, Y. Linder-Berrebi, and V. MiévilleOtt. 2007. Vegetationsdynamik und Erwartung der Bevölkerung an die Landschaft. AgrarForschung 16:402407.

Gronow, A. 2008. Not by rules or choice alone: a pragmatist critique of institution theories in economics and sociology. Journal of Institutional Economics 4:351-373. http://dx.doi. org/10.1017/S1744137408001124

Gunderson, L. H., and C. S. Holling, editors. 2002. Panarchy: understanding transformations in human and natural systems. Island Press, Washington D.C., USA.

Hodgson, G. M. 1998. The approach of institutional economics. Journal of Economic Literature 36:166-192.

Hollingsworth, J. R. 2000. Doing institutional analysis: implications for the study of innovations. Review of International Political Economy 7:595-644. http://dx.doi. org/10.1080/096922900750034563

Lebel, L., J. M. Anderies, B. Campbell, C. Folke, S. HatfieldDodds, T. P. Hughes, and J. Wilson. 2006. Governance and the capacity to manage resilience in regional social-ecological systems. Ecology and Society 11(1):19. [online] URL: http:// www.ecologyandsociety.org/vol11/iss1/art19/
Lehmann, B., and P. Messerli. 2007. The Swiss national research programme "Landscapes and habitats of the Alpine Arc". Journal of Alpine Research 4:19-28.

Mack, G., T. Walter, and C. Flury. 2008. Entwicklung der Alpung in der Schweiz: Ökonomische Bedeutung und ökologische Auswirkungen. Yearbook of Socioeconomics in Agriculture:259-300.

McGinnis, M. D. 2011. Networks of adjacent action situations in polycentric governance. Policy Studies Journal 39 (1):5178.

McGinnis, M., and E. Ostrom. 2010. IAD and SES dynamic flows: introducing the Program in Institutional Analysis of Social-Ecological Systems (PIASES) framework. Preliminary draft of a paper to be presented at 13th Economics of Infrastructures Conference, Delft, Netherlands.

Nägeli-Örtle, R. 1986. Die Berglandwirtschaft und Alpwirtschaft in Grindelwald. Schlussbericht zum Schweizerischen MAB-Programm. Nr. 21. Bern, Switzerland.

Netting, R. M. C. 1981. Balancing on an Alp: ecological change and continuity in a Swiss mountain community. Cambridge University Press, Cambridge, UK.

North, D. C. 1990. Institutions, institutional change and economic performance. Cambridge University Press, Cambridge, UK. http://dx.doi.org/10.1017/CBO9780511808678

Olsson, P., L. H. Gunderson, S. R. Carpenter, P. Ryan, L. Lebel, C. Folke, and C. S. Holling. 2006. Shooting the rapids: navigating transitions to adaptive governance of socialecological systems. Ecology and Society 11(1):18. [online] URL: http://www.ecologyandsociety.org/vol11/iss1/art18/

Ostrom, E. 1990. Governing the commons: the evolution of institutions for collective action. University Press, Cambridge, UK. http://dx.doi.org/10.1017/CBO9780511807763

Ostrom, E. 2005. Understanding institutional diversity. Princeton University Press, Princeton, New Jersey, USA.

Ostrom, E. 2007. A diagnostic approach for going beyond panaceas. Proceedings of the National Academy of Sciences of the United States of America 104(39):15181-15187. http:// dx.doi.org/10.1073/pnas.0702288104

Ostrom, E. 2008. Developing a method for analyzing institutional change. Pages 48-76 in S. S. Batie and N. Mercuro, editors. Alternative institutional structures: evolution and impact. Routledge, New York, New York, USA. http://dx.doi.org/10.4324/9780203894439.ch3

Ostrom, E. 2009. A general framework for analyzing sustainability of social-ecological systems. Science 325:419422. http://dx.doi.org/10.1126/science. 1172133 
Ostrom, E., and X. Basurto. 2011. Crafting analytical tools to study institutional change. Journal of Institutional Economics 7:317-343. http://dx.doi.org/10.1017/S1744137410000305

Redman, C. L., J. M. Grove, and L. H. Kuby. 2004. Integrating social science into the long-term ecological research (LTER) network: social dimensions of ecological change and ecological dimensions of social change. Ecosystems 7:161171. http://dx.doi.org/10.1007/s10021-003-0215-z

Schensul, S. L., J. J. Schensul, and M. D. LeCompte. 1999. Essential ethnographic methods: observations, interviews, and questionnaires. Altamira Press, Plymouth, UK.

Schlager, E., and E. Ostrom. 1992. Property-rights regimes and natural resources: a conceptual analysis. Land Economics 68:249-262. http://dx.doi.org/10.2307/3146375

Schlüter, A., and I. Theesfeld. 2010. The grammar of institutions: the challenge of distinguishing between strategies, norms, and rules. Rationality and Society 22:445475. http://dx.doi.org/10.1177/1043463110377299

Smit, B., and J. Wandel. 2006. Adaptation, adaptive capacity and vulnerability. Global Environmental Change 16:282-292. http://dx.doi.org/10.1016/j.gloenvcha.2006.03.008

Stevenson, G. G. 1991. Common property economics: a general theory and land use applications. Cambridge University Press, Cambridge, UK. http://dx.doi.org/10.1017/ CBO9780511528361

Stöcklin, J., A. Bosshard, G. Klaus, K. Rudmann-Maurer, and M. Fischer. 2007. Landnutzung und biologische Vielfalt in den Alpen. Fakten, Perspektiven, Empfehlungen. Synthese NFP 48. Hochschulverlag ETH Zürich, Zurich, Switzerland.

Termeer, C., A. Dewulf, and M. van Lieshout. 2010. Disentangling scale approaches in governance research: comparing monocentric, multilevel, and adaptive governance. Ecology and Society 15(4):29. [online] URL: http://www. ecologyandsociety.org/vol15/iss4/art29/

Tiefenbach, M., and A. G. Mordasini. 2006. Bergschaften in Grindelwald. Alppflege zwischen Tradition und Moderne. Sutter Druck AG, Grindelwald, Switzerland.

Turner, B., and P. Robbins. 2008. Land-change science and political ecology: similarities, differences, and implications for sustainability science. Annual Review of Environment and Resources 33:295-316. http://dx.doi.org/10.1146/annurev. environ.33.022207.104943

Volken, T., I. Kissling-Näf, and W. Zimmermann. 2002. Die Nutzung von Alpweiden im Wandel. ETH Zürich, Switzerland. [online] URL: http://www.pepe.ethz.ch/ publications/archive/weitere publikationen/2002/

fallstudie_brieschern_2002.pdf
Walker, B., C. S. Holling, S. R. Carpenter, and A. Kinzig. 2004. Resilience, adaptability and transformability in socialecological systems. Ecology and Society 9(2):5. [online] URL: http://www.ecologyandsociety.org/vol9/iss2/art5/

Wiesmann U. 2001. Umwelt, Landwirtschaft und Tourismus im Berggebiet-Konfliktbearbeitung im Leitbild Grindelwald 2000. Pages 237-249 in Studien für europäische Friedenspolitik, Band 7: Die Umwelt- Konfliktbearbeitung und Kooperationen. Agenda Münster, Münster, Germany. 